Miroslav Vaněk

[Praga]

\title{
Słuchać, poszukiwać, rozumieć. \\ Nie tylko o dialogu \\ interdyscyplinarnym i oral history
}

Wrocławski Rocznik

Historii Mówionej

Rocznik VII, 2017

ISSN 2084-0578

DOI: $10.26774 /$ wrhm.168

Wzrost popularności oral history w ostatnich dwóch dekadach jest w naszym środowisku zrozumiały i udokumentowany ${ }^{1}$. Narracje, które opowiadamy, narracje, których słuchamy, mówią o doświadczeniu życiowym, o materialnych i metafizycznych aspektach ludzkiego bytu. Aktywują wyobraźnię i wzbudzają pragnienie zrozumienia samego siebie, innych i świata, w którym żyjemy. A chodzi tu o kwestie zasadnicze: kim jesteśmy? Dokąd zmierzamy? Co uznajemy za dobre, a co za złe? Dlaczego robimy właśnie to, co robimy?

Po tym, jak w latach 6o. XX w. oral history zdobyła uznanie na Zachodzie, pod koniec lat 8o. XX w. nabrała nowego wiatru w żagle w związku ze zmianami politycznymi i społecznymi, do których doszło w Europie Środkowej i Wschodniej, w Ameryce Południowej czy w Afryce Południowej, a dziś jesteśmy świadkami jej wielkiego rozkwitu w Azji. Oral history jest

Artykuł powstał dzięki wsparciu the Grant Agency of the Czech Republic 410/17${ }_{14167}$ S, w ramach projektu „The Student Generation of 1989 in Longitudinal Perspective: Biographical Interviews after Twenty Years". 
104 bezsprzecznie związana z wolnością: tam, gdzie wolność jest zagwarantowana, a ludzie sami w nią wierzą, oral history ma się dobrze. W warunkach braku wolności przeciwnie - realizowanie badań metodą oral history jest praktycznie niemożliwe, ponieważ ludzie boją się mówić o swojej przeszłości i teraźniejszości. Ponadto tego rodzaju działalność badawcza pozbawiona jest wówczas wsparcia akademickiego czy uniwersyteckiego, a także jakiegokolwiek finansowania. W odróżnieniu od badań archiwalnych, które władze państwowe mogą uniemożliwić po prostu poprzez zamknięcie archiwów, niezależne projekty oral history mogłyby być nadal realizowane, w warunkach braku wolności są to jednak jedynie wyjątki potwierdzające regułę. Dlatego też przed 1989 r. w Czechosłowacji i całej Europie Środkowej i Wschodniej nie były niestety prowadzone żadne niezależne (z dzisiejszego punktu widzenia) badania oral history. Do przełomu doszło dopiero w ostatniej dekadzie minionego wieku.

Kogo uznać można za pioniera metody oral history? To zależało od warunków lokalnych, tradycji i szczęścia. W części krajów u początków rozwoju dyscypliny stali etnolodzy czy folkloryści, gdzie indziej byli to historycy, antropolodzy czy socjolodzy. Wszyscy w jakimś zakresie potrzebowali do swych badań metody oral history i w różny sposób się z nią mierzyli i mierzą do dziś².

Zrozumienie siebie samego jako punkt wyjścia do rozumienia innych. Kim jesteśmy jako badacze oral history?

O ile przenikanie się różnych dyscyplin jest w dzisiejszych czasach uznawane za pożądane, a owa interdyscyplinarność może ubogacać poszczególne dziedziny, to jeszcze większe znaczenie ma to w wypadku spotkań

Valerie Yow twierdzi, że chociaż „pamięć jest powszechnie uznawanym źródłem historycznym, historia jest tylko jedną z wielu dyscyplin akademickich i dziedzin intelektualnych, które pracują ze wspomnieniami”. Autorka mówi o „efekcie przenikania" z innych dyscyplin, na przykład socjologii jakościowej, antropologii, studiów biograficznych czy literaturoznawczych (wyliczenie to dopełnić należy o studia kulturoznawcze, lingwistyczne, nauki o komunikacji, zajmujące się relacjami pamięci, tożsamości narratora i tożsamości jednostki). „Podczas gdy wkład teoretyczny i metodologiczny we wspomnianych obszarach wzbogacił praktykę oral history, badacze oral history postarali się o rozwój teorii, metodologii i «polityki» badań jakościowych"; zob. V. Yow, Do I Like Them Too Much? Effects of the Oral History Interview on the Interviewer, „Oral History Review”, 24/1 (1997), s. 59. 
międzynarodowych. Wystarczy otwarta głowa, pokora i szacunek dla innych dyscyplin, wraz z pragnieniem uczenia się od innych i rozwijania własnej dyscypliny. Oral history może tu odegrać niepoślednią rolę i być jednym z potencjalnych spoiw wielu dziedzin. Mimo to spotykamy się niekiedy z pewnymi defensywno-purystycznymi stanowiskami pojedynczych reprezentantów rozlicznych dyscyplin humanistycznych i społecznych. Mnie interesuje coś dokładnie odwrotnego, niż wzajemne odgradzanie się, to jest poszukiwanie nowych możliwości, które oferuje oral history, łączenie wysiłków i próby odnajdywania metod skutecznych w zgłębianiu życia wewnętrznego człowieka i jego rzeczywistości społecznej, zarówno w niedawnej przeszłości, jak i w teraźniejszości ${ }^{3}$. Staram się znajdować możliwości, jakie oferuje oral history, które są antytezą dla uwypuklania specyfiki poszczególnych dyscyplin, reprezentowanych raczej jedynie przez jednostki, które ze sobą nie rozmawiają, a czasem wręcz (chociaż nie otwarcie) sobą pogardzają. Obrońcy poszczególnych dyscyplin nie powinni się obawiać, że ktokolwiek będzie im cokolwiek narzucał i przekonywał ich o jedynej słusznej prawdzie. Zawsze pierwszorzędny będzie kontekst i priorytety danej dyscypliny, które są z góry zdefiniowane i determinują sposób prowadzenia wywiadów i ich wykorzystania. Oral history w rozumieniu interdyscyplinarnym to dla mnie szukanie wspólnych podstaw, uczenie się od siebie nawzajem. Zgadzam się w tym z Alistairem Thomsonem, który przed laty powiedział mi:

Kolejna rzecz, która jest tak pociągająca w oral history, to jej interdyscyplinarność: są tu nie tylko historycy, ale także antropolodzy, pracownicy muzeów, ludzie zajmujący się psychologią społeczną, lingwiści... Zmusza to pana, jako historyka, do wyjścia poza swoje wąskie szufladki, zmierzenia się z literaturą i metodologią z całego szeregu dyscyplin. Stopniowo staje się pan taką intelektualną sroką. Musi pan skakać za ideami jak ptak, który przynosi cudze rzeczy do gniazda. Badacze

\footnotetext{
Nie jestem jedynym, który się o to stara. W tym nurcie w 2015 r. Pavel Mücke wystąpił z wykładem dla archiwistów pod tytułem Konkurenci czy partnerzy? Tekst zob.: P. Mücke, Orální historie a archivnictví: konkurenti či partneři?, [w:] Učiteli archivářu. Jindřichu Swippelovi kosmdesátinám, Praha 2015, s. 41-46. W podobnym duchu Pavel Mücke i Miroslav Vaňek przygotowali wykład: Využití orální historie $v$ kronikárství: nástin teorie a praxe, który odbył się we wrześniu 2016 r. pod patronatem kronikarzy Republiki Czeskiej.
} 
oral history są jak sroki, musimy brać pomysły z różnych dyscyplin, różnych kultur i krajów, byśmy to, co robimy, robili jak najlepiej4.

Alistair Thomson jest przedstawicielem prawie pięćdziesięcioletniej tradycji oral history obecnej na przykład w Stanach Zjednoczonych, Wielkiej Brytanii czy Australii, która wzajemne interdyscyplinarne wzbogacanie się uznaje za wartość. Jednak również w przestrzeni Europy Środkowej pojawiają się czasem (ostatnio w polskiej Łodzi, a także w słowackiej Banskiej Stiavnici) działania socjologów czy etnologów, którzy nie tylko zadeklarowali się jako badacze oral history, lecz także zorganizowali ich międzynarodowe spotkanie ${ }^{5}$, odgraniczając swoje dziedziny od oral history. W żadnym razie nie nawołuję do bezkrytycznego przyjmowania metodologii oral history przy prowadzeniu, analizowaniu i interpretacji wywiadów. Przeciwnie - namawiam do tego, byśmy na swoją pracę spojrzeli krytycznie i starali się uczyć od siebie nawzajem. Według mnie różnorodność dziedzin reprezentowanych przez badaczy i badaczki oral history jest jej zaletą, siłą, i będzie tak aż do momentu, kiedy stanie się jej słabością. Do czego, jak wierzę, nie dojdzie.

Przy tej okazji chciałbym wspomnieć o kwestii wielokrotnie dyskutowanej za granicą: czy oral history to swego rodzaju metoda badawcza, samodzielna dyscyplina czy „tylko” specyficzne źródło powstałe na podstawie wywiadu? Podoba mi się, że w tej kwestii nie ma jednomyślności. Zamknięcie się wokół jednej z opcji prowadzi bowiem do zablokowania dalszego rozwoju. Dobrze, że posiadanie własnego zdania nie zmusza nas do wykluczenia innego. W tym kontekście przemawia do mnie pogląd czeskiego archiwisty Jindricha Schwippela, który charakteryzuje oral history jako: swego rodzaju heurystykę („źródłem jest dla nas świadek, którego musimy odnaleźć i uzyskać od niego świadectwo"); wdrożenie nauki o źródłach (ponieważ poszukując źródeł

4 M. Vaňek, O orální historii s jejími zakladateli a protagonisty, „Ústav pro soudobé dějiny AV ČR" (2008), s. 105.

$5 \quad$ W Łodzi polscy koledzy (przede wszystkim jednak socjolodzy, historycy i antropolodzy) zorganizowali pod auspicjami Polskiego Towarzystwa Historii Mówionej konferencję, mającą wesprzeć kolegów z całej Europy Środkowej i Wschodniej (International Conference „Oral history in Central-Eastern Europe: Current research areas, challenges, and specificity, 17-18 IX 2015 r., Łódź). Słowaccy etnolodzy i muzealnicy zorganizowali natomiast 2o. edycję konferencji „Etnológ $\mathrm{v}$ teréne, $\mathrm{k}$ prameňom poznania" - odbyła się ona w dniach 21-23 VI 2016 r. w Banskiej Stiavnici. 
informacji musimy od początku oceniać ich kompetencje informacyjne, ich wiarygodność, weryfikowalność itd.; metodę, która uczy, jak w najwłaściwszy i najskuteczniejszy sposób pozyskiwać i wykorzystywać informacje; swego rodzaju źródło historyczne ${ }^{6}$ i w końcu - dodaję od siebie - oral history jest wyjątkowym materiałem do analizy i interpretacji. Schwippel dodaje jeszcze: „moje doświadczenie archiwistyczne mówi mi, że oral history jest prawdopodobnie jedyną łatwą do wykorzystania rekompensatą «klasycznych» archiwaliów pisemnych, które w komputerowym wieku e-maili, telefonów komórkowych itd. zaczynają znikać”7.

Nawet granice między akademicką a amatorską gałęzią oral history nie są, jak sądzę, nie do przekroczenia. Podobnego zdania jest także Alistair Thomson, podkreślając, że „kolejną wspaniałą cechą oral history jest to, że inicjuje dialog ze światem akademickim, który musi uczyć się, co się dzieje poza akademią; podobnie świat pozaakademicki musi czerpać z wypracowanych metod naukowych, które powstają właśnie tam”. Jedynym „ograniczeniem” dla obu światów jest zaakceptowanie w całości etycznego wymiaru oral history. Etyka bowiem jest jednym z podstawowych filarów badań. Jedną z najważniejszych zasad etycznych przy prowadzeniu badań oral history jest szacunek wobec narratora jako przekaziciela opowieści biograficznej. Pytający - jako specjalista i przedstawiciel środowiska naukowego (to samo dotyczy amatorów) - nie powinien w żadnym wypadku ani w żadnej fazie badań przystępować do nich z zamiarem manipulacji. Poruszamy się tu na granicy między odpowiedzialnością wobec narratora, który powierzył nam swoją opowieść, a oczekiwaniami innych badaczy, tych, którzy korzystają z archiwów czy zbiorów oral history. To wcale nie jest proste.

Skoro wspomniałem o interdyscyplinarności i specjalizacji w obszarze oral history, nie powinniśmy pomijać również pespektywy generacyjnej i genderowej. Z własnego doświadczenia wiem, że historycy „starej szkoły”, poza wyjątkami, nie mieli żadnego pojęcia o nowych metodach badań historycznych, w tym o oral history (przed 1989 r. było to niemal niemożliwe), a co więcej nawet ich nie poszukiwali (dotyczy to też historyków działających na emigracji). Jeszcze w latach 70. i na początku 80. XX w. wśród historyków przeważał

6 J. Schwippel, Orální historie a archivy, „Archivní časopis Praha“, 56 (3), s. 177-184. Ibidem.

8 M. Vaněk, O orálni historii... 
sceptycyzm wobec oral history i wobec problematyki badań pamięci, z podkreślaniem niewiarygodności powstałego w ten sposób źródła. Oral history jest więc dziś przede wszystkim polem badawczym młodej i średniej generacji. Jeżeli chodzi o perspektywę gender, należy zauważyć, że mężczyźni-historycy (którzy w naukach historycznych przeważają) skupiali się raczej na analizie tzw. wielkich wydarzeń dziejowych, politycznych i wojskowych, ewentualnie ekonomicznych, w większości opartej na studiach źródeł pisanych. Ochoczo i uprzejmie pozostawiali swoim koleżankom pozostałe „małe tematy”. Ja natomiast sądzę, że nie ma małych tematów, są tylko mali historycy. Nie zaskakuje zbytnio to, że dziś w środowisku oral history pracuje więcej kobiet niż mężczyzn. Z tych względów osobiście uważam to za logiczne i w dłuższej perspektywie pozytywne. Także dlatego, że kobiety są zasadniczo bardziej empatyczne, podczas wywiadu umieją lepiej słuchać czy usunąć w cień własną osobowość, własne ego.

Moje podejście do oral history wyznacza perspektywa historyka dziejów współczesnych i badacza, który z oral history styka się i potyka od ponad dwudziestu lat. Podstawowym założeniem, z którym się utożsamiłem i które uważam za nośne, jest uwaga Michaela Frischa o stosunku oral history do „wielkiej” historii, „wydarzeń dziejowych” czy też do problematyki pamięci, bez czego nie możemy się w naszej pracy obejść.

Oral history jest trzecią stroną trójkąta. Trójkąt można rozumieć ogólnie jako schemat obrazujący trzy podstawowe źródła i podejścia, z których powstaje historia jako całość i historyczny produkt. Pierwszy wierzchołek to ludzkie przeżywanie przeszłości i jego amatorska interpretacja, tzw. life story lub w szerszym pojęciu pamięć (indywidualna, kolektywna itd.). Drugi wierzchołek to „klasyczna” historia wielkich wydarzeń i procesów (event story), trzecim wierzchołkiem tego wyobrażonego trójkąta jest łącząca oba podejścia oral history ze wszystkim, co ze sobą przynosi ${ }^{9}$.

To właśnie oral history, oparta na dwóch pozostałych wspomnianych wyżej filarach, może korzystać z włączenia narracji do kontekstu, który jest zrozumiały dla szerokiej publiczności. Oral history wnosi bowiem zdolność poznawania historii w perspektywie komparatystycznej. Wykorzystywana w historiografii i spełniająca wszelkie kryteria podejścia naukowego musi

9 M. Vaněk, P. Mücke, Třetí strana trojúhelníku. Teorie a praxe orální historie, Praha 2015, s. 13 . 
bowiem opierać się na trzech podstawowych zasadach: znajomości metodologii, znajomości kontekstu historycznego i społecznego epoki, a także na etyce. Czy jednak wszystko to, na co jako specjaliści jesteśmy przygotowani, wystarczy?

\section{Tracimy dialog, tracimy opowieści - i co dalej?}

Coraz rzadziej spotykamy ludzi, którzy chcą opowiadać historie, którzy opowiadać historie umieją. Za to coraz częściej spotykamy się z zawstydzeniem, które pojawia się zawsze, kiedy ktoś jest gotów historii wysłuchać. To tak, jakby pozbawiono nas czegoś, o czym myśleliśmy, że jest nie do odebrania - naszą najbardziej podstawową właściwość: zdolność do wymiany doświadczeñ ${ }^{10}$.

Jakiś czas temu, w jednej z praskich kawiarni, byłem świadkiem swoistego „dialogu” dwóch nastolatek. Usiadły przy stoliku, zamówiły kawę i każda zaczęła stukać w swój telefon komórkowy. Nie wymieniły ze sobą ani jednego słowa. Po dwudziestu minutach zapłaciły i odeszły. Dwie żywe istoty uwięzione w przezroczystych bańkach, z jednej strony połączone z globalną siecią, z drugiej zaś - same. Czy ten obrazek jest zapowiedzią nowej „komunikacji" czy też przedstawia jedynie chwilowe odchylenie od normalnego ludzkiego funkcjonowania, którego integralną częścią są język i mowa? Być może rzeczywiście przesunęliśmy się do sfer, o których przedtem nie mieliśmy nawet pojęcia. Dziś ludzie tracą zdolność zauważania siebie nawzajem, w ich interakcjach przeważają monologi. Tymczasem bez dialogu, opowiadania i słuchania społeczność ludzka nie może funkcjonować i nie funkcjonuje.

Osiemdziesiąt lat po opublikowaniu cytowanego wyżej artykułu Waltera Benjamina znajdujemy się w nieco schizofrenicznej sytuacji; zupełnie naturalnie potrzebujemy opowieści biograficznych, a mimo to coraz bardziej się od nich (i od „sztuki” ich opowiadania) oddalamy. Oczywiście komunikujemy się także dziś. Problemy jednak stwarza nam prowadzenie rozmów międzypokoleniowych, pozazawodowych - towarzyszy im jakieś zażenowanie i niepewność (pewni siebie jesteśmy już tylko w swoim specyficznym środowisku komunikacyjnym), zderzenie twarzą w twarz z obcą osobą staje się stresujące.

10 W. Benjamin, Der Erzähler. Betrachtungen zum Werk Nikolai Lesskows, 1936, [w:] Illuminationen. Ausgewählte Schriften 1., Frankfurt/M. 1977, s. 385-410. 
Trend dzisiejszych czasów jest zupełnie inny - szybkość, zwięzłość, jakaś typowość i uproszczenie. Wybieramy krótkie wiadomości mailowe, esemesy, uczestniczymy w wyselekcjonowanych wydarzeniach w sieciach społecznościowych. Wielu z nas ma przy tym nadzieję (co potwierdzają dokładne badania), że ten "komunikacyjny” świat jest sztuczny, uproszczony, bardzo oddalony od świata realnego, w którym prawdziwi ludzie przeżywają swoje biografie, wypełnione przeżyciami, doświadczeniami, a także życiową mądrością. Sieci społecznościowe, które mają potencjał łączenia każdego z każdym, kto jest „w sieci”, są według specjalistów źródłem bardzo niebezpiecznego uzależnienia, które ma już swoją nazwę. Chodzi tu o tzw. confirmation bias, a więc potwierdzanie własnych stereotypowych sądów, które przejawia się tendencją do wyszukiwania jedynie takich poglądów i dowodów, które stworzony stereotyp potwierdzą. „Sieci społecznościowe zastępują ludzkie wspólnoty", twierdzi polsko-brytyjski socjolog Zygmunt Bauman, i dodaje, że podstawowa różnica między wspólnotą a siecią polega na tym, że

jako człowiek należysz do wspólnoty, ale sieć należy do ciebie. Możesz dodać przyjaciela, jeżeli będziesz chciał, możesz go odrzucić, jeżeli będziesz sobie tego życzył. Pozornie jesteś wolny, ale w praktyce jesteś pod wpływem ważnych osób, wśród których chcesz się znaleźć. W nowych sieciach społecznościowych ludzie czują się lepiej, mniej opuszczeni. Samotność i opuszczenie są straszakiem naszego wieku indywidualizmu ${ }^{11}$.

Ludzie stopniowo tracą umiejętności społeczne, których potrzebują, o ile opuszczą swoje wygodne fotele i wyjdą naprzeciw realnemu życiu, prawdziwym, codziennym interakcjom. Tymczasem wiele dzieci żyje w „nienaturalnym" środowisku już od wczesnych lat - przedszkola dla wybranych, gimnazja w miejsce szkół podstawowych, wybrane zajęcia dodatkowe, wybrani koledzy... Gdzie dzisiejsze dzieci mają się nauczyć komunikacji ze zwyczajną, tzn. niewyselekcjonowaną z góry populacją? Oczywiście nie wspominam z nostalgią obowiązkowej służby wojskowej. Muszę jednak przyznać, że miała jedną niezaprzeczalną zaletę - nauczyła mniej komunikować się, mówić

11 Z. Bauman, Social media are a trap. The Polish-born sociologist is skeptical about the possibilities for political change. Interview in El País, 25 I 2016, http://elpais.com/ elpais/2016/o1/19/inenglish/1453208692_42466o.html (dostęp: 14. VI 2016 r.). Więcej o wpływie mediów społecznościowych zob. Z. Bauman, D. Lyon, Tekutý dohled, Olomouc 2013, s. 29-57. 
i słuchać ludzi z różnych grup społecznych, etnicznych czy wyznaniowych, w tym mężczyzn z wyrokami czy ludzi, jak to się obecnie mówi, społecznie nieprzystosowanych. Oni również mieli swoje opowieści biograficzne, także oni chcieli się nimi z różnych powodów dzielić. Dialog nie powinien być ograniczony jedynie do grupy ludzi, którzy nadają na tej samej fali, są tego samego „wyznania”, co my.

Sieci społecznościowe nie uczą nas dialogu, raczej zapobiegają kontrowersjom. Większość ludzi nie wykorzystuje mediów społecznościowych, by uczyć się krytycznego myślenia, by poszerzyć horyzonty, ale dokładnie odwrotnie. Sieci społecznościowe odcinają użytkowników od wpływów zewnętrznych i tworzą tzw. strefę komfortu, gdzie jedynymi dźwiękami, które słyszycie, są echa waszego własnego głosu, gdzie jedyne obrazy, które widzicie, to odbicia własnej twarzy. Media społecznościowe są użyteczne, bo oferują przyjemność, ale są także pułapką ${ }^{12}$.

Dlaczego wprowadzam tu tę dygresję dotyczącą dialogu - nie-dialogu? Może dlatego, że oral history jest ściśle związana z tym problemem. Daje możliwość, nad którą się zbytnio nie zastanawialiśmy, o której nie wspominaliśmy - oral history przyczynia się do podtrzymania tradycji, można powiedzieć konserwatywnej ludzkiej zdolności, sztuki prowadzenia dialogu. W ten sposób zachowuje także dla przyszłych pokoleń niemożliwą do zastąpienia mądrość życiową.

\section{Kontekst, kontekst, kontekst...}

Rozmowa może mieć wiele form; chodzi jedynie o to, w jaki sposób rozumieją ją obaj protagoniści: może być wyjątkowym spotkaniem, pełnym empatii i otwartości; wykładem historii, wyznaniem; pojedynkiem werbalnym; ćwiczeniem z nostalgii; lub jakąkolwiek inną formą, w której ludzie rozmawiają o swoich doświadczeniach. Wywiady oral history stanowią dla historyka cenne źródło nowej wiedzy o przeszłości i nowej pespektywy interpretacyjnej. Wywiady są zawsze formowane przez kontekst, w którym są przeprowadzane (cel rozmowy, zakres, na który się obaj, pytający i narrator, przygotowywali, stan ich myśli, stan fizyczny itd.), a także przez szczególną międzyludzką dynamikę między narratorem a pytającym.

12 Z. Bauman, Social media... 
Trzeba jednak również zauważyć, że wywiady, nawet mimo znacznej wartości, nie są nieproblematycznym źródłem. Narratorzy sami podejmują decyzję o tym, co powiedzieć, a czego nie. Podobnie jak w przypadku każdego innego źródła, także tu historycy muszą ćwiczyć się w myśleniu krytycznym i ocenie źródła - to, że ktoś barwnie i przekonująco twierdzi, że coś jest prawdą, nie musi jeszcze oznaczać, że to rzeczywiście prawdą jest. Jak mówi historyk Linda Shopes, „Tylko to, że narrator «był przy tym», nie oznacza jeszcze, że w pełni zrozumiał, co mu się przydarzyło"13. Sprzeczności i konflikty wewnątrz poszczególnych wywiadów i między wywiadami a innym rodzajem świadectw wskazują jednoznacznie na subiektywną naturę oral history. Nie należy zapominać, że podobnie jak narratorzy, także pytający mają pewną społeczną tożsamość, co ma wpływ na dynamikę rozmowy. Narratorzy oceniają pytających i decydują, na powiedzenie tego, na co mogą sobie pozwolić, co powiedzieć muszą i czego - przeciwnie - powiedzieć nie powinni. Poglądy narratorów mogą się z biegiem czasu zmieniać, w zależności od „klimatu” politycznego, społecznego, ekonomicznego czy osobistego. Ich stanowisko się poszerza lub zawęża wskutek nowych doświadczeń, które na przykład skłaniają do przewartościowania pierwotnych poglądów, współczesne uwarunkowania formują rozumienie minionych zdarzeń.

Podobnie jak całe społeczeństwo, narratorzy nie są odporni na różne zawirowania polityczne, które przeszliśmy $\mathrm{w}$ minionych dwudziestu kilku latach. Uwielbienie, a następnie potępienie środowisk dysydenckich, budowa paradygmatu bohaterstwa, fala antykomunizmu, fala podawania w wątpliwość skali represji reżimu normalizacyjnego, podobnie jak utożsamianie tego okresu z latami 5o. XX w. ... Te najróżniejsze zwroty doprowadziły ostatecznie do utraty pewnego gruntu przez narratorów. Są to przecież w ogromnej większości przede wszystkim zwykli ludzie, którzy siebie, swojej historii nie znaleźli ani w oficjalnie głoszonej historii minionego ustroju, ani w tej od nowa pisanej historii polistopadowej. Ich westchnienie nad „pisaniem od nowa” historii zgodnie z hasłem „zwycięzca bierze wszystko” jest ostrzeżeniem. Nie możemy machnąć na nie ręką. Jest jasne, że historia współczesna jest w swym założeniu niedokończona i nowe interpretacje przeszłości będą

13 L. Shopes, Making Sense of Oral History, [w:] Oral History in the Digital Age, 2012, http://ohda.matrix.msu.edu/2012/o8/making-sense-of-oral-history/ (dostęp: 14 VI 2016 r.). 
się pojawiać, to jest w porządku. Nie do obrony są interpretacje instrumen-

talnie polityczne, które powinny być obłożone publicznym zakazem.

Wielu narratorów w ostatnich kilku latach odrzuca dyskurs, który wszystko, co było przed 1989 r. opisuje jako bezwartościowe i bezduszne. Nie identyfikują się oni z nową interpretacją historii, a przeszłości nie pamiętają, jak sami mówią, w taki sposób, w jaki jest dziś opisywana. To oczywiście nie musi jeszcze oznaczać, że historia jest pisana źle. Nie musi jednak także oznaczać, że ci, którzy z nostalgią wspominają własną przeszłość, są od razu apologetami poprzedniego systemu.

Tym, co jest (a w przyszłości może być) znaczące dla naszej dyscypliny, jest, jak się wydaje, wzrastająca niechęć narratorów i narratorek do wspominania przeszłości. Jest nam coraz trudniej, trudniej, niż się kiedykolwiek spodziewaliśmy, zaprosić i skłonić do rozmowy „zwykłych ludzi”, i to nawet wśród tych grup obywateli, po których byśmy tej niechęci nie oczekiwali. Jedna ze studentek kierunku oral history - historia współczesna z niewielkimi jedynie sukcesami kontaktowała się z muzykami rockowymi (!) w zachodnich Czechach. Kilka razy odmówiono jej z wyjaśnieniem, że ich poglądy (nie chodziło o członków Komunistycznej Partii Czechosłowacji) nie pasują do dzisiejszej wielkiej narracji, która wszystko, co było przed 1989 r., ocenia jako złe. („Myślę, że nie jestem właściwym obiektem opowieści o historii... moje spojrzenie na okres, który był dla mnie fantastyczny, nikogo by nie interesowało i nie pasowałoby do dzisiejszej nagonki na komunę [...]. Każdy nowy system poprawia sobie historię tak, jak mu w tym momencie wygodnie"14). Inna studentka tego samego kierunku przytoczyła w swojej pracy magisterskiej, jak pewna para małżeńska odmówiła jej udzielenia wywiadu z podobnym wyjaśnieniem, że „chociaż nie byli członkami partii, musieliby częściowo bronić minionego reżimu, musieliby wspomnieć, że w latach 70. i 80. mogli brać udział w wielu wydarzeniach kulturalnych, pozbawionych kontekstu politycznego i że nie chcą o tym w wywiadzie mówić, bo to dziś jest niemodne" ${ }^{15}$. Nie trzeba tu przywoływać kolejnych alarmujących sygnałów, by wzbudzić naszą czujność.

14 L. Marková, Plzeňská hudební scéna 1968-1983, mps. Diplomová práce, Praha 2015, Fakulta humanitních studií Univerzity Karlovy, s. 16.

15 S. Petracchi, Roudnické strojírny a slévárny, n. p. a jejich význam pro život místního obyvatelstva v obdobi tzv. normalizace a prvni fázi transformace, mps, Praha 2015, Fakulta humanitních studií Univerzity Karlovy, s. 13. 


\section{Rewolucyjność oral history dziś}

Coraz częściej zderzamy się z całą plejadą często przeciwstawnych interpretacji, w których współczesność spotyka się z przeszłością i w których dyskurs naukowy spotyka się z instrumentalnym, zideologizowanym przez polityków pojęciem historii. Na głębszą analizę wspominanej tendencji nie ma miejsca w tym artykule. Niech nam w tym momencie wystarczy konstatacja, że właśnie oral history może być użytecznym narzędziem korygującym głęboko zakorzenione uogólnienia i ideologiczne wzorce myślenia.

Koledzy z Zachodu w tym wypadku nam nie pomogą i pomóc nie mogą. Ich historia nowożytna nie była tyle razy (a niekiedy nie była wcale) przerywana epokami rządów reżimów totalitarnych czy autokratycznych ze wszystkimi konsekwencjami, jakie z tego płyną. Będziemy musieli liczyć na siebie, na dyskusje, które przeprowadzimy z koleżankami i kolegami o podobnych doświadczeniach historycznych. $\mathrm{Z}$ nimi będziemy szukać metod przekonywania narratorów i narratorek, że jako badacze oral history nie osądzamy ludzi, że życie może biec różnymi drogami, że bohaterstwem może być także sensowne wypełnienie jednego „zwykłego” życia. Właśnie w tym mógłby się przejawić aktywizm, który był charakterystyczny dla oral history od jej nowoczesnych początków.

Gdyby oral history stała się tubą establishmentu, stałaby się własnym zaprzeczeniem. Oral history nie porusza się po wcześniej zaprojektowanych trajektoriach, przeciwnie, jest świadoma, że życie prywatne jest zawsze pierwszą rzeczą, którą zabiera człowiekowi ideologia. I ta sama ideologia, kiedy już przejmie władzę, stara się wcisnąć ludzi do odgórnie zdefiniowanych szablonów. Oral history nie jest ważna jedynie ze względu na studia nad totalitaryzmem, ale także nad dziejami transformacji. Dla nowych elit zgromadzone wywiady również wcale nie muszą być łaskawym lustrem. Nie jest prawdą, że wywiady z ludźmi, którzy nie sprawowali władzy politycznej ani nie byli bohaterami (z jakiegokolwiek punktu widzenia), są bezwartościowe. Wywiady z ludźmi „bezsilnymi” są dla zrozumienia epoki równie ważne, jak wywiady z ludźmi, którzy otwarcie występowali przeciw minionemu reżimowi czy z tymi, którzy współtworzyli ówczesną władzę.

Kolejne pokolenia historyków i uczonych będą analizować kontekst, w którym powstawały relacje świadków. Na tej podstawie będą zajmować swoje stanowisko, tak samo, jak czynimy dziś my. Musimy przedstawić, czego świadkiem była miniona i obecna epoka. Jest to zadanie historyków, ale także przedstawicieli innych dyscyplin nauk społecznych, którzy - każdy w inny sposób (tematyczny, metodologiczny) - przyczyniają się do ogólnego 
poznania życia człowieka w różnych epokach i w różnych środowiskach społecznych. Jestem przekonany, że możemy być znacznie więcej niż tylko użyteczni. Dzięki wspólnocie zainteresowań, w których centrum znajduje się człowiek z jego autentycznymi ludzkimi doświadczeniami, możemy dojść do wspólnych wniosków, wzajemnego zrozumienia i szacunku.

Sądzę, że nie ma lepszego sposobu na opisanie ludzkiego losu niż osobista narracja. Opowiadane historie przypominają nam światy mało znane lub nawet już nieistniejące. Nawet mimo znacznego niekiedy oddalenia (geograficznego czy kulturowego) narracje biograficzne mogą się często wydawać dobrze znanymi. W miarę stopniowego zagłębiania się w wewnętrzny świat narratorów, znajdujemy bliskie i dalekie, odmienne i wspólne. Spektrum różnorodnych głosów pomaga nam uczyć się tolerancji. Czy jest lepszy sposób, by zrozumieć siebie i innych? Ja go nie znam.

Tłumaczenie z języka czeskiego Katarzyna Uczkiewicz 


\section{Bibliografia}

Bauman Z., Social media are a trap. The Polish-born sociologist is skeptical about the possibilities for political change. Interview in El País, 25 I 2016, http://elpais.com/elpais/2016/01/19/ inenglish/1453208692_42466o.html

Bauman Z., Lyon D., Tekutý dohled, Olomouc 2013

Benjamin W., Der Erzähler. Betrachtungen zum Werk Nikolai Lesskows, 1936, [w:] Illuminationen. Ausgewählte Schriften 1., Frankfurt/M. 1977

Marková L., Plzeňská hudební scéna 1968-1983, mps. Diplomová práce, Praha 2015, Fakulta humanitních studií Univerzity Karlovy

Mücke P., Orální historie a archivnictví” konkurenti či partneři?, [w:] Učiteli archivářo. Jindřichu Swippelovi k osmdesátinám, Praha 2015, s. 41-46

Petracchi S., Roudnické strojírny a slévárny, n. p. a jejich význam pro život místního obyvatelstva $v$ období tzv. normalizace a první fázi transformace, mps, Praha 2015, Fakulta humanitních studií Univerzity Karlovy

Schwippel J., Orální historie a archivy, „Archivní časopis Praha“, 56 (3), s. 177-184

Shopes L., Making Sense of Oral History, [w:] Oral History in the Digital Age, 2012, http://ohda. matrix.msu.edu/2012/o8/making-sense-of-oral-history/

Vaňek M., O orální historii s jejími zakladateli a protagonisty, „Ústav pro soudobé dějiny AV ČR“, (2008)

Vaněk M., Mücke P., Třetí strana trojúhelníku. Teorie a praxe orální historie, Praha 2015

Yow V., Do I Like Them Too Much? Effects of the Oral History Interview on the Interviewer, „Oral History Review", 24/1 (1997) 
The author, from the perspective of a contemporary history researcher, indicates the potential common foundations, but also the differences in using the oral history method in an interdisciplinary perspective. Based on practical experience, he concludes that the assumptions of oral history and other disciplines for which research material is a conversation, are very similar. The difference between the particular fields lies in each one's specific methods. This article is a reflection on certain current oral history problems. The author's starting point is the current situation, where on the one hand there is an increasing interest in oral history, because of a human need for stories, but on the other hand, people are losing their ability to tell stories or listen to them intently more and more every day. On this occasion, he introduces the issue of the speed of life in today's times, striving for simplicity and conciseness in the context of a narrative relationship. The author continues to deal with some methodological issues that have not been given special attention to in the past. This is particularly true about the problem of subjectivity, memory and its role in the construction of biographical narratives, and the issue of social and political context (both past and present) in which interviews are carried out. In the end, the author indicates how the study of oral history helps to learn and understand not only the past but also the present. In fact, this is the great strength of this method, in this aspect it is an inspiration for researchers in other fields of social sciences, for which conversation is the basic source.
Miroslav Vaněk

Listen, search, understand. Not only about interdisciplinary dialogue and oral history

Key words: oral history, social sciences, methodology 